\title{
Trace element accumulation in the shell of the Arctic cirriped Balanus balanus
}

\author{
A. Iglikowska $\cdot$ M. Ronowicz $\cdot$ E. Humphreys-Williams $・$ P. Kukliński
}

Received: 12 October 2017/Revised: 11 February 2018/Accepted: 25 February 2018/Published online: 3 March 2018

(C) The Author(s) 2018. This article is an open access publication

\begin{abstract}
Barnacles are widespread and abundant inhabitants of rock surfaces in the intertidal zone, providing considerable contributions to the formation of carbonate sediments. The main goal of this study was to test two hypotheses: (1) the chemical composition of the Balanus balanus shell is mostly controlled biologically, and environmental factors have only minor influences, and (2) the chemical composition of B. balanus shells does not vary with size. To test these hypotheses, samples were collected in two fjords from two depths. This study revealed site-related differences in shell chemistry, although no variability in shell chemical compositions was detected between the
\end{abstract}

Handling editor: Iacopo Bertocci

Electronic supplementary material The online version of this article (https://doi.org/10.1007/s10750-018-3564-5) contains supplementary material, which is available to authorized users.

A. Iglikowska $(\varangle) \cdot$ M. Ronowicz $\cdot$ P. Kukliński

Marine Ecology Department, Institute of Oceanology

Polish Academy of Sciences, Powstańców Warszawy 55,

81-712 Sopot, Poland

e-mail: annaiglikowska@gmail.com

E. Humphreys-Williams

Imaging and Analysis Centre, The Natural History

Museum, Cromwell Road, London SW7 5BD, UK

P. Kukliński

Department of Life Sciences, The Natural History

Museum, Cromwell Road, London SW7 5BD, UK depths and among the size categories. Barnacle shell plates had different accumulation patterns for different trace elements $(\mathrm{Mg}, \mathrm{S}, \mathrm{Sr})$, with the operculum as the most distinctive shell plate. As those plates are precipitated under the same environmental conditions, the different accumulation patterns may indicate biological control of element uptake in cirripedes. We suggest that the specific chemical composition of the operculum may be related to the required mechanical properties of this shell part, and thus, it is likely that this organism regulates accumulation patterns within its shell, because such regulation increases its adaptive properties. Our results supported both presented hypotheses.

Keywords Barnacle - Calcifier - Biomineralization Geochemical cycles $\cdot$ Ocean acidification

\section{Introduction}

Adult cirripedes (barnacles) are sessile crustaceans that are permanently attached to natural or man-made hard substrata (Newman \& Abbott, 1980). Barnacles are important contributors to ecosystems providing nutrient cycling, food and habitat (Findlay et al., 2009). Balanus balanus (Linnaeus, 1758) is a common inhabitant of the northern seas (Barnes \& Barnes, 1954) and is typically found at all depths to $150 \mathrm{~m}$ (Smith, 2015), with a preference for depths between 
20 and $30 \mathrm{~m}$ (Barnes \& Barnes, 1954). Sessile organisms are unable to move away from environmental disturbances; therefore, they must evolve special adaptations in their morphology and physiology to face changing external conditions. Adult barnacles possess a hard, calcareous shell that provides protection against predators, desiccation, abrasion, and other physical and mechanical pressures (Rainbow, 1984). There are several studies on the variations in shell shape in relation to ecological conditions (e.g. Gutmann, 1960), shell growth and formation (e.g. Darwin, 1854; Klepal \& Barnes, 1975), shell microstructure (e.g. Bourget, 1977) and shell chemistry (e.g. Gordon et al., 1970; Bourget, 1987). The shell of most cirripedes is calcitic, but in some warm water species, aragonite is present in the basal part of the shell (Bourget, 1987).

The barnacle shell consists of several types of plates that are in different shapes and different locations. The cone-shaped shell of Balanus stands on a basal, calcareous plate firmly attached to the substratum. The lateral walls of the shell consist of rostral plates, carinal plates, and two or four lateral plates (Fig. 1). In all acorn barnacles, the aperture is protected by two pairs of movable, thick opercular plates: terga and scuta. Opercular plates can be open or closed, and with closed operculum, barnacles retain water in the mantle cavity, which reduces stress during low tide or other adverse environmental conditions. However, despite this mechanism, there are a variety of factors such as predation, competition, food availability, siltation, exposure, pollution, temperature, salinity, and $\mathrm{pH}$

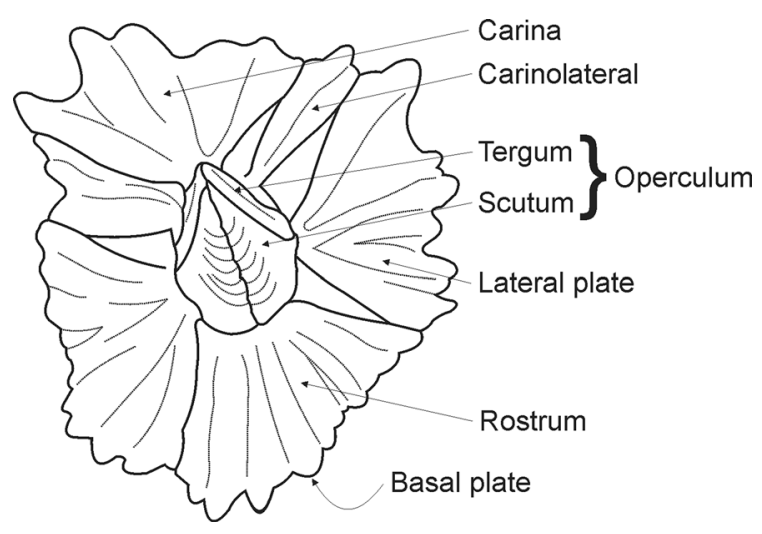

Fig. 1 Schematic drawing of Balanus balanus shell (view from above) showing the location of specific shell plates
(Buckeridge, 2012) that may limit their natural occurrence.

Due to global warming, Arctic marine environments are changing at an unprecedented scale and rate in terms of seawater temperature, sea-ice cover, $\mathrm{pH}$ and ocean circulation (e.g. Bulling et al., 2010; Hönisch et al., 2012). Declines in seawater pH (ocean acidification), occurring due to increased emissions of atmospheric $\mathrm{CO}_{2}$, are currently one of the most important ecological problems, especially in the Arctic (e.g. Andersson et al., 2008; Feely et al., 2008). In laboratory conditions, growing barnacles enhanced $\mathrm{CaCO}_{3}$ production in seawater at a $\mathrm{pH}$ of 7.4 , although their shells appeared to be significantly weaker compared to specimens reared at a $\mathrm{pH}$ of 8.2 (McDonald et al., 2009). $\mathrm{CO}_{2}$-driven ocean acidification may also alter the behaviour of metals in seawater and sediments, changing their availability for organisms (Roberts et al., 2013). Most marine invertebrates tend to accumulate trace metals in their tissues, and these elements are typically derived from ambient seawater that crosses permeable epithelial surfaces and from food that crosses the digestive track (Rainbow, 2006). Many species of barnacles feed by filtration of small suspended particles from the water column, and those suspended particles are a potential metal source (Rainbow, 2006). Barnacles are known to be strong accumulators of trace metals (Rainbow, 2006). Most metals are deposited in soft body parts (Rainbow, 2006), although there is little knowledge about trace elements that are preferentially accumulated in the calcareous shell. Trace metals are not primary constituents of carbonate lattice; however, their presence in biogenic minerals is common. The composition of trace elements might provide an insight into the conditions under which shell precipitation occurred and how these elements modify the growth and properties of final calcareous skeletons. On the other hand, knowledge of shell chemistry is useful to estimate which elements will be transferred back to the environment after the death of an organism during the processes of dissolution and diagenesis. Therefore, the distribution of trace elements in calcareous shells is of interest from several perspectives, including geochemical cycles, calcification processes and palaeoecology. In numerous marine species, skeletal chemistry varies and directly reflects environmental conditions. Our understanding of factors influencing the uptake of trace elements into 
barnacle shells may provide information about the mechanisms shaping the process of biomineralization in marine calcifiers. It is particularly important for Arctic species, because Arctic ecosystems become rapidly unfavourable for calcifying species due to progressing hypercapnia and declining carbonate saturation (e.g. Andersson et al., 2008).

The main aim of this study was to test following hypotheses: (1) the chemical composition of cirriped Balanus balanus shell is mostly controlled biologically, with minor influences from environmental variables, and (2) the chemistry of B. balanus shell does not change during growth. To test these hypotheses, the concentrations of selected minor and trace elements were determined in the shell of the Arctic $B$. balanus. Specific shell parts are characterized by different locations and functions that may be reflected in the differences in element concentrations. In previous papers, only entire barnacle shells have been examined in terms of shell chemistry (e.g. Gordon et al., 1970; Watson et al., 1995). In the present study, each shell plate was analysed separately to reveal the potential variations in chemical composition within a single specimen. As the entire structure of an individual develops under the same environmental conditions, observed differences in chemical composition among the different structures of the B. balanus lead to the assumption that different element concentrations in specific shell plates would indicate the biological control of element uptake and retention in the shell. In addition, the biological control of shell chemistry was examined by the relationships between the elemental composition and size class of the barnacle shells, to determine whether accumulation patterns change with growth. We assume that specimens living at the same station are thus exposed to the same nutritional and abiotic environmental conditions and likely exhibit similar growth rates. Consequently, younger specimens are expected to possess smaller shells compared to older specimens. Finally, we attempted to reveal the interdependence between barnacle shell chemistry and both the site location and depth to assess the influence of environmental variables on shell precipitation.

\section{Materials and methods}

Study area

The study area was located on the western coast of Spitsbergen, the largest island in the Svalbard Archipelago. Balanus balanus samples were collected from two fjords: Kongsfjorden and Hornsund.

Kongsfjorden $\left(79^{\circ} 55^{\prime} \mathrm{N}, 11^{\circ} 56^{\prime} \mathrm{E}\right)$ is a glacial fjord situated on the northwestern part of Spitsbergen. The entire fjord is approximately $20 \mathrm{~km}$ long and from 4 to $10 \mathrm{~km}$ wide. The inner basin of Kongsfjorden is relatively shallow $(<100 \mathrm{~m})$ although the outer part that directly connects with the North Atlantic Ocean is much deeper, with a maximum depth exceeding $300 \mathrm{~m}$. The fjord is fed by two tidal glaciers (Kongsbreen and Kronebreen) that may locally reduce salinity, as much as down to 20 (Ito \& Kudoch, 1997). The shores are steep and rocky, and the bottom slopes are steep, with occasional horizontal terraces. Weakly declining slopes and deeper areas are covered by soft glacial sediments (Jørgensen \& Gulliksen, 2001; Lippert et al., 2001).

The Hornsund fjord $\left(76^{\circ} 57^{\prime} \mathrm{N}, 15^{\circ} 46^{\prime} \mathrm{E}\right)$ that is located at the southernmost area in Spitsbergen is $30 \mathrm{~km}$ long and up to $15 \mathrm{~km}$ wide. The average depth of the fjord is $90 \mathrm{~m}$, with the maximum depth at $260 \mathrm{~m}$. The fjord floor is diverse, but it is more homogenous compared to Kongsfjorden (Drewnik et al., 2016). The bottom along the coastline has a steep slope, although patches of flat bottom are also observed (Drewnik et al., 2016). In the deeper parts of the fjord, the seabed is covered mostly with finegrained and homogenous sediment with a variable content of sand (Grzelak \& Kotwicki, 2012).

The hydrographic conditions of the study area vary seasonally and are shaped mainly by complex interactions between Atlantic and Arctic water masses. Atlantic waters are characterized by higher temperatures and salinity levels $\left(T>3^{\circ} \mathrm{C}, S=34.65\right)$, while Arctic water masses are colder and contain less saline waters $\left(T=-1.5-1.0^{\circ} \mathrm{C}, S=34.30\right.$; Cottier et al., 2005). Both currents flow northward, and they are separated by a frontal region (Cottier et al., 2005). Despite its location further on the south, Hornsund has more Arctic characteristics than Kongsfjorden due to the strong polar front that is created between the Arctic waters of the Sørkapp current and the Atlantic waters of the West Spitsbergen Current and that reduces the 
inflow of warm Atlantic waters into the fjord (Walczowski, 2013).

On the west coast of Spitsbergen, primary production increases in the spring, and during April, the chlorophyll $a$ concentration in the phytoplankton biomass starts at $20-25 \mathrm{mg} \mathrm{m}^{2}$ and increases to $250 \mathrm{mg} \mathrm{m}^{2}$ by the middle of May (Hop et al., 2002). In May and June, the sea-ice melts contributing to the stratification of the surface water layer, and hence, fjords are largely influenced by melting water discharge (Hop et al., 2002; Svendsen et al., 2002). Water masses provide different concentrations of nutrients and carbon; therefore, their relative proportions may affect carbonate chemistry in seawater.

In the summer of 2014, Hornsund fjord was characterized by the mean surface water $\mathrm{CO}_{2}$ at $14.29 \mu \mathrm{mol} \mathrm{kg}{ }^{-1}$, and $\mathrm{CO}_{2}$ concentrations increased gradually from $16.19 \mu \mathrm{mol} \mathrm{kg} \mathrm{kg}^{-1}$ at a $50 \mathrm{~m}$ depth to $17.91 \mu \mathrm{mol} \mathrm{kg}^{-1}$ at $100 \mathrm{~m}$, reaching lower values (16.77 $\mu \mathrm{mol} \mathrm{kg}^{-1}$ ) at a $150 \mathrm{~m}$ depth (Iglikowska et al., 2017). The $\mathrm{CO}_{2}$ values for Kongsfjorden showed an increasing trend from the lowest concentrations in the surface waters $\left(11.83 \mu \mathrm{mol} \mathrm{kg}{ }^{-1}\right)$ to the highest concentrations at $150 \mathrm{~m}\left(18.53 \mu \mathrm{mol} \mathrm{kg}{ }^{-1}\right)$. The calcite saturation $(\Omega \mathrm{Ca})$ varied in Hornsund, from 2.71 at $150 \mathrm{~m}$ to 3.03 at $50 \mathrm{~m}$, and these values were sufficient for calcite-forming organisms, although at greater depths, lower calcite saturation is expected. In Kongsfjorden, seawaters were also well saturated, with the lowest $\Omega \mathrm{Ca}$ values (2.81) at $150 \mathrm{~m}$ and the highest values (3.32) at the surface waters (Iglikowska et al., 2017).

Sample collection and preparation

Balanus balanus specimens were obtained during the cruise of R/V Oceania (Institute of Oceanology Polish Academy of Sciences, Sopot, Poland) in July and August 2014. Samples were collected by dredging at three localities in west Spitsbergen (Fig. 2) and from three different depths: 50, 100 and $150 \mathrm{~m}$. A list of collection sites with geographic positions, sampling dates and depths is given in Appendix 1-Supplementary material.

After collection, barnacles were carefully removed from their substrates (mainly rocks and bivalve shells) using a razor blade, and then, they were immediately frozen $\left(-20^{\circ} \mathrm{C}\right)$. In the laboratory, each individual was initially checked under a stereomicroscope to confirm taxonomic identification. Subsequently, the soft tissue was thoroughly removed and empty shells were rinsed with deionized water. The biofilm covering the shells was removed using ultrasound washer (InterSonic IS-7S) and then, shells were dried at $60^{\circ} \mathrm{C}$. Epibionts were scraped with razor from the shells. The size (i.e. basal rostro-carinal diameter) of each barnacle shell was measured using a slide calliper, and then, three size classes were established: small (1-10 mm), medium (10-15 mm) and large ( $>15 \mathrm{~mm}$ ) (Appendix 1 -Supplementary material). Then, specimens were dissected, and shell plates were separated using razor blades and forceps. Figure 1 shows the location of the specific shell parts within the B. balanus specimen. For further elemental analysis, four specimens were split into specific shell parts, and each shell part was analysed separately. In the remaining individuals, only one plate, namely, the lateral plate, was considered in the chemical analyses. Prior to the analysis, each shell piece was crushed and homogenized using an agate mortar and pestle.

\section{Elemental analyses}

The trace element compositions of the $B$. balanus shells were determined at the Imaging and Analysis Centre at the Natural History Museum, London, UK. All laboratory tools and materials were prepared for use by being digested in $2 \mathrm{M} \mathrm{HNO}_{3}$ (TraceSELECT ${ }^{\circledR}$ $\mathrm{HNO}_{3}$ from Fluka Analytical) for $24 \mathrm{~h}$, and then, they were thoroughly rinsed in ultrapure milliQ water to prevent a potential source of contamination. Briefly, after weighing, the powdered samples were digested using $1.5 \mathrm{~cm}^{3}$ concentrated $(70 \%) \mathrm{HNO}_{3}$ (trace metal grade purity) and $0.3 \mathrm{~cm}^{3}$ hydrogen peroxide, and after, they were left overnight in a drying chamber at $70^{\circ} \mathrm{C}$. Then, the solutions were diluted to a final volume of $15 \mathrm{~cm}^{3}$. Major ( $\left.\mathrm{Ca}, \mathrm{Na}, \mathrm{Mg}, \mathrm{S}\right)$, minor ( $\mathrm{P}$, $\mathrm{Sr})$ and trace $(\mathrm{Ba}, \mathrm{Mn})$ elements were quantified by inductively coupled plasma-atomic emission spectroscopy (ICP-AES) on a Thermo iCap 6500 Duo (Cambridge, UK). Quality control of the analysis was provided by standards, certified reference material (Japanese Limestone, JLs-1 and Japanese Dolomite, JDo-1-Geological Survey of Japan) and blank reagents that were run within each sample batch. The analytical accuracy of the method was within $4 \%$ of the standard value for all studied elements. 
Fig. 2 The studied area and sampling locations for Balanus balanus specimens. Geographic positions, depths and other characteristics are available in Appendix 1Supplementary material

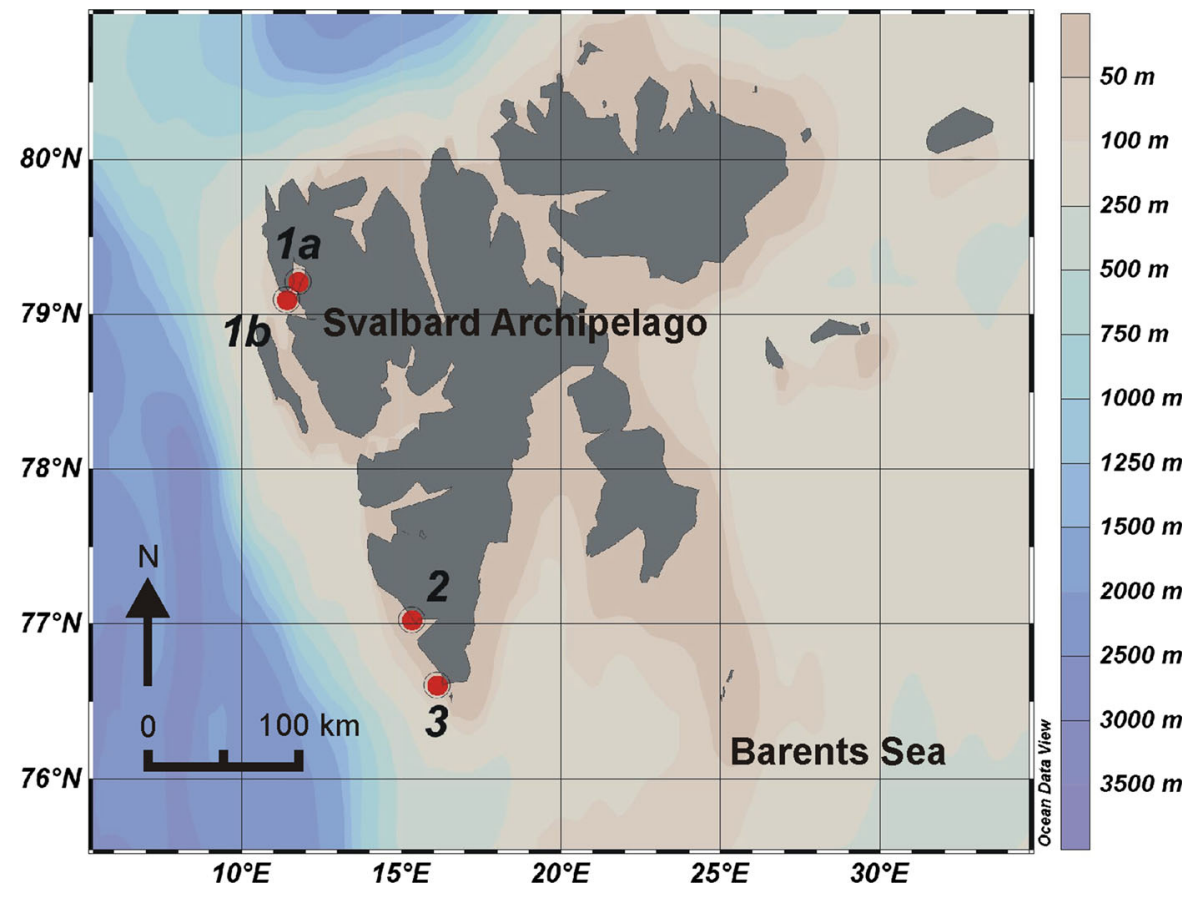

To check the validity of the data, the $\mathrm{Mg}$ and $\mathrm{Ca}$ contents were recalculated as $\mathrm{MgCO}_{3}$ and $\mathrm{CaCO}_{3}$ of the dry weight and combined. Samples having $\mathrm{CaCO}_{3}$ content between 60 and $101 \%$ were taken into account in the statistical analyses. If the sum of $\mathrm{MgCO}_{3}$ and $\mathrm{CaCO}_{3}$ was greater than $101 \%$, the data were discarded; similarly, when the total was less than $60 \%$, then the data were deemed to be inaccurate, and then again, the values were discarded. In our study, we have chosen to avoid chemical pre-treatment, which may affect the carbonate chemistry, but the consequence of this method was that some minor organic material can be still associated with inorganic component, therefore the $\mathrm{Ca}$ and $\mathrm{Mg}$ values that fall outside of $60-101 \%$ were likely. Thus, for error corrections, all elemental concentrations in B. balanus shells were expressed as ratios over $\mathrm{Ca}\left(\mathrm{mmol} \mathrm{mol}{ }^{-1}\right)$ to reduce the effect of organic particles still present on a shell or within the calcium carbonate lattice.

\section{Mineralogical analysis}

In the studied barnacles, the shell mineralogy and concentration of $\mathrm{MgCO}_{3}$ were measured using powder X-ray diffraction (XRD-PSD, Enraf-Nonius FR590, with position-sensitive detector) and were conducted at the Imaging and Analysis Centre at the Natural
History Museum, London, UK. Powdered samples were placed on a flat sapphire substrate and then loaded into a circular rotary mount. The adopted time for each analysis was $15 \mathrm{~min}$. The $\mathrm{MgCO}_{3}$ content in the calcite was measured from the position of the $d_{104}$ peak assuming a linear change in $\mathrm{d}_{104}$ with composition. A linear relationship between $\mathrm{d}_{104}$ and $\mathrm{MgCO}_{3}$ content was expected to exist between 0 and $20 \mathrm{~mol} \%$ $\mathrm{MgCO}_{3}$ in calcite (e.g. Mackenzie et al., 1983), and all measurements in this study were included within this range. All studied barnacle shells were characterized by calcite mineralogy, with low $\mathrm{MgCO}_{3}$ concentrations (up to $4.5 \mathrm{~mol} \% \mathrm{MgCO}_{3}$ ).

\section{Statistical analysis}

The dependent variable in the analyses was shell chemistry, i.e. element ratios of $B$. balanus shell plates: $\mathrm{Ba} / \mathrm{Ca}, \mathrm{Mg} / \mathrm{Ca}, \mathrm{Mn} / \mathrm{Ca}, \mathrm{Na} / \mathrm{Ca}, \mathrm{P} / \mathrm{Ca}, \mathrm{S} / \mathrm{Ca}, \mathrm{Sr} /$ $\mathrm{Ca}$, and analyses were carried out with untransformed data.

To reveal potential differences between specific shell plates, four specimens were selected, and the chemical composition of each plate was examined separately: specimen 1 (samples: B20, B22, B23, B24, B25 and B26), specimen 2 (B27, B28, B29, B30, B33), specimen 3 (B41, B42, B43, B44, B45, B46 and B47) 
and specimen 4 (B48, B49, B50, B51, B52, B53 and B54) (see details in Appendices 1 and 2-Supplementary material). To examine the differences in shell chemistry between pairs of specific plates of shells between specimens, the Wilcoxon paired test was used (STATISTICA 12 package). One-way PERMANOVA (permutation multivariate analysis of variance) was applied to the Euclidean distance-based similarity matrix to analyse the spatial variability in the chemical compositions between specific shell plates. Shell plates were treated as a fixed factor with 6 levels. Euclidean distance was used as a measure of resemblance in the multivariate analyses due to the specificity of the dataset, which is more related to the type of environmental (sensu Clarke \& Gorley, 2006) than the biological community structure; therefore, Euclidean distance is more appropriate to use in the multivariate analyses (Clarke \& Gorley, 2006). Furthermore, we applied a constrained ordination of CAP (canonical analysis of principal coordinates) to depict the interrelationships between the potential chemical determinants of the shell part patterns (Anderson et al., 2008). The CAP analysis is available in the PRIMER package (ver. 7).

The dataset of the elemental compositions of lateral plates $(N=31)$ was divided a priori according to sampling site (two fjords: warmer Kongsfjorden and colder Hornsund), depth (50,100 m) and three size classes based on the basal rostro-carinal diameter of the shell (small, medium, large). To test the difference in chemical composition during growth, both multivariate (all element/Ca ratios) and univariate (for each single element/Ca ratio) one-way PERMANOVA models with a 3-level fixed factor 'size' were applied using a Euclidean distance matrix. The effects of location and depth on Balanus shell chemistry were tested with the two-way PERMANOVA model. Two fixed factors were used: location (two levels: Hornsund and Kongsfjorden) and depth (two levels: 50 and $100 \mathrm{~m}$ ), and their interactions were included. The resemblance measure used was Euclidean distance. PERMANOVA does not require normal distributions of original variables, and the $\mathrm{p}$ and pseudo- $F$ values were calculated based on 9999 unrestricted permutations of the raw data. PERMANOVA analyses were run using the PRIMER 7 software package (Anderson, 2001; Anderson et al., 2008).

\section{Results}

In total, 445 measurements were obtained from 64 shell plates and 36 specimens of Balanus balanus (Appendix 1-Supplementary material). The mean concentrations of each element have been summarized in Table 1. Elements found in the highest ratios (major elements) were $\mathrm{Na} / \mathrm{Ca}$ (mean $20.49 \mathrm{mmol} \mathrm{mol}^{-1 \text { - }}$ $\pm 3.33 \mathrm{SD}), \mathrm{Mg} / \mathrm{Ca}\left(14.83 \mathrm{mmol} \mathrm{mol}{ }^{-1} \pm 4.13\right)$ and S/Ca (11.87 mmol mol $\left.\mathrm{mm}^{-1} \pm 4.15\right)$, whereas $\mathrm{Mn} /$ $\mathrm{Ca} \quad\left(0.077 \mathrm{mmol} \mathrm{mol}^{-1} \pm 0.058\right)$ and $\mathrm{Ba} / \mathrm{Ca}$ $\left(0.055 \mathrm{mmol} \mathrm{mol}^{-1} \pm 0.018\right)$ were recorded at significantly lower (trace) levels. No statistically significant differences in element ratios were found between the studied individuals (Appendix 2-Supplementary material), except for $\mathrm{Mn} / \mathrm{Ca}$ where significant differences were observed between specimen 1 (B20-B26) and 3 (B41-B47), 1 and 4 (B48-B54), and 3 and 4 (Wilcoxon paired test: $W=21, P=0.031 ; W=21$, $P=0.031 ; W=28, P=0.016$, respectively).

The one-way PERMANOVA global test confirmed statistically significant differences among specific shell plates of $B$. balanus (pseudo- $F=10.86$, $P<0.001$ ). Additionally, a detailed analysis showed that the operculum was the most distinctive skeletal part in terms of chemical composition (Table 2), with higher ratios of $\mathrm{Mg} / \mathrm{Ca}$ (mean $20.34 \mathrm{mmol} \mathrm{mol}^{-1 \text { - }}$ $\pm 2.35 \mathrm{SD})$ and $\mathrm{S} / \mathrm{Ca}\left(18.17 \mathrm{mmol} \mathrm{mol}^{-1} \pm 1.74\right)$ and significantly lower $\mathrm{Sr} / \mathrm{Ca}$ values (3.59 mmol mol $\mathrm{mm}^{-1} \pm 0.25$ ) compared to other skeletal parts (Figs. 3 and 4). In the studied specimens, $\mathrm{Mg} / \mathrm{Ca}, \mathrm{S} / \mathrm{Ca}$ and $\mathrm{Sr} / \mathrm{Ca}$ had the most variable concentrations among their skeletal parts (Fig. 4), while the remaining elements had less clear patterns.

Table 1 Mean ratios ( $\mathrm{mmol} \mathrm{mol}{ }^{-1}$ ), standard deviations (SD) and ranges of trace elements for all studied samples $(N=64)$

\begin{tabular}{lcc}
\hline Element & Mean ratio $\pm \mathrm{SD}$ & Range \\
\hline $\mathrm{Mg} / \mathrm{Ca}$ & $14.83 \pm 4.13$ & $9.20-26.45$ \\
$\mathrm{Sr} / \mathrm{Ca}$ & $3.85 \pm 0.26$ & $3.12-4.35$ \\
$\mathrm{Ba} / \mathrm{Ca}$ & $0.055 \pm 0.018$ & $0.023-0.122$ \\
$\mathrm{Mn} / \mathrm{Ca}$ & $0.077 \pm 0.058$ & $0.023-0.397$ \\
$\mathrm{Na} / \mathrm{Ca}$ & $20.49 \pm 3.33$ & $13.91-33.69$ \\
$\mathrm{P} / \mathrm{Ca}$ & $1.25 \pm 0.75$ & $0.19-5.95$ \\
$\mathrm{~S} / \mathrm{Ca}$ & $11.87 \pm 4.15$ & $1.51-20.66$ \\
\hline
\end{tabular}


Table 2 Post hoc test from PERMANOVA examining relationships between each pair of shell plates

\begin{tabular}{llr}
\hline Shell plates & $t$ & $P$ value \\
\hline Lateral plate \& carina & 0.569 & 0.767 \\
Lateral plate \& operculum & 6.586 & $<\mathbf{0 . 0 0 1}$ \\
Lateral plate \& rostrum & 0.488 & 0.876 \\
Lateral plate \& basal plate & 2.483 & $\mathbf{0 . 0 2 0}$ \\
Lateral plate \& carinolateral & 1.296 & 0.209 \\
Carina \& operculum & 6.193 & $\mathbf{0 . 0 0 1}$ \\
Carina \& rostrum & 0.563 & 0.771 \\
Carina \& basal plate & 2.609 & $\mathbf{0 . 0 1 6}$ \\
Carina \& carinolateral & 1.186 & 0.282 \\
Operculum \& rostrum & 5.588 & $<\mathbf{0 . 0 0 1}$ \\
Operculum \& basal plate & 2.235 & $\mathbf{0 . 0 2 5}$ \\
Operculum \& carinolateral & 4.940 & $\mathbf{0 . 0 0 9}$ \\
Rostrum \& basal plate & 2.224 & $\mathbf{0 . 0 3 8}$ \\
Rostrum \& carinolateral & 0.616 & 0.762 \\
Basal plate \& carinolateral & 1.671 & 0.101 \\
\hline
\end{tabular}

Statistically significant $P$ values are bolded

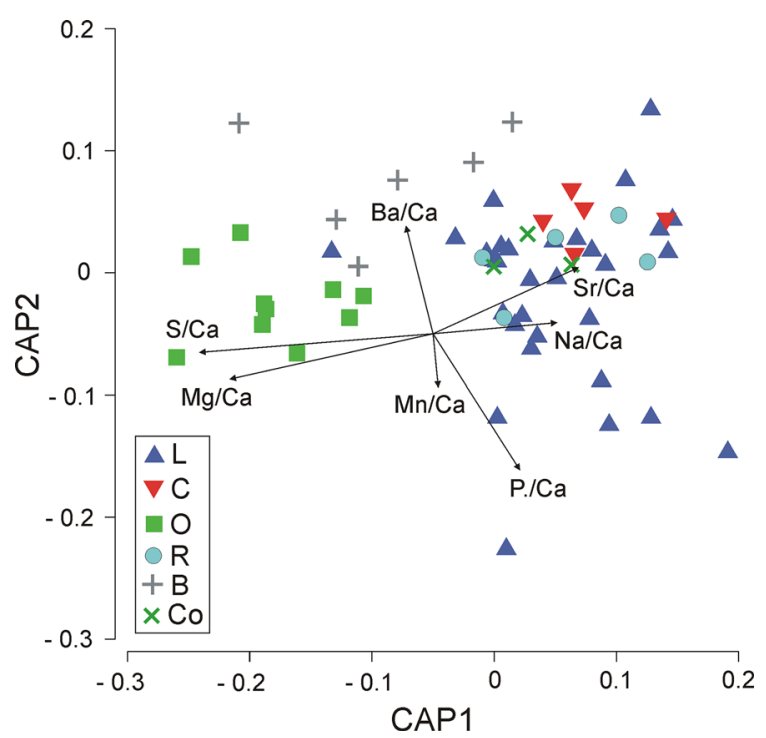

Fig. 3 Diagram of canonical analysis of principal coordinates (CAP) for 64 B. balanus plates, displaying the chemical composition of specific shell plates. Abbreviations of the shell parts: $L$ lateral plate, $C$ carina, $O$ operculum, $R$ rostrum, $B$ basal plate, Co carinolateral (see Fig. 1)

Because the differences in shell chemistry between specific shell plates were statistically significant, in further analyses, we must consider the chemical composition of lateral plates only, measured in 31 specimens (Appendix 1-Supplementary material). Using PERMANOVA, we examined the effect of depth and location (fjord) on the chemical composition of the lateral shell plates. Based on the multivariate test, their interactive influence was insignificant, although the impact of the factor 'fjord' appeared to have a significant effect (Table 3). Additionally, in the univariate test, we observed variation in the shell ratios of $\mathrm{Mn} / \mathrm{Ca}$ (pseudo- $F=13.9, P<0.001$ ), $\mathrm{Na} / \mathrm{Ca}$ (pseudo- $F=5.4, \quad P=0.026$ ) and $\mathrm{P} / \mathrm{Ca}$ (pseudo$F=5.5, \quad P=0.019)$ depending on site location (Fig. 5). The lateral plates of the specimens collected from Hornsund were characterized by higher $\mathrm{Mn} / \mathrm{Ca}$ (mean $0.138 \mathrm{mmol} \mathrm{mol}^{-1} \pm 0.097 \mathrm{SD}$ ), $\mathrm{Na} / \mathrm{Ca}$ $\left(22.87 \mathrm{mmol} \mathrm{mol}^{-1} \pm 4.45\right)$ and $\mathrm{P} / \mathrm{Ca}$ (2.04 mmol mol ${ }^{-1} \pm 1.30$ ) ratios compared to lower values observed in the plates of individuals from Kongsfjorden $\quad\left(0.050 \mathrm{mmol} \mathrm{mol}^{-1} \pm 0.019\right.$, $19.75 \mathrm{mmol} \mathrm{mol}^{-1} \pm 1.87$ and $1.11 \mathrm{mmol} \mathrm{mol}^{-1-}$ \pm 0.36 , respectively) (Fig. 5).

One-way PERMANOVA confirmed the lack of statistically significant differences in lateral plate chemistry between the three different size classes (pseudo- $F=1.77, P=0.11$ ); however, in a more detailed univariate analysis, we confirmed size-dependent differences for two elements: $\mathrm{Ba} / \mathrm{Ca}$ (PERMANOVA global test: pseudo- $F=4.03, P=0.049$ ) and $\mathrm{Na} / \mathrm{Ca}$ (PERMANOVA global test: pseudo$F=4.30, P=0.033)$. Post hoc pairwise comparisons revealed differences between the groups of size 'large' and 'small' in both cases $(t=3.05, P=0.005$ and $t=2.41, P=0.020$, respectively). These two elements exhibited contradictory trends (Fig. 6): larger (older) individuals were characterized by higher $\mathrm{Ba} /$ Ca ratios (mean $0.062 \mathrm{mmol} \mathrm{mol}^{-1} \pm 0.021 \mathrm{SD}$ ) and lower $\mathrm{Na} / \mathrm{Ca}$ values $\left(19.68 \mathrm{mmol} \mathrm{mol}^{-1} \pm 2.59\right.$ for medium individuals and $20.41 \mathrm{mmol} \mathrm{mol}^{-1} \pm 1.87$ for large individuals), whereas small (younger) specimens showed lower $\mathrm{Ba} / \mathrm{Ca}$ ratios $\left(0.036 \mathrm{mmol} \mathrm{mol}^{-1} \pm 0.011\right)$ and higher $\mathrm{Na} / \mathrm{Ca}$ values $\left(24.04 \mathrm{mmol} \mathrm{mol}^{-1} \pm 5.65\right.$, Fig. 6) in their lateral shell plates.

Seven B. balanus samples, representing seven different shell plates, were analysed to determine shell mineralogy, and all of shell plates were entirely calcitic. The $\mathrm{MgCO}_{3}$ concentration, measured by means of XRD, was relatively low, with a mean of $3.3 \mathrm{~mol} \%$ and range of $2.3-4.5 \mathrm{~mol} \%$ (Fig. 7). All 

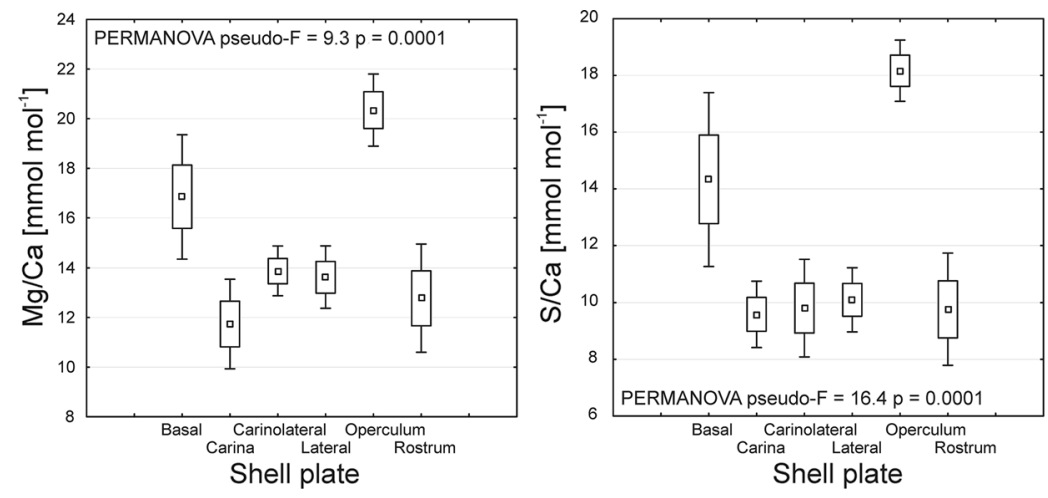

Shell plate

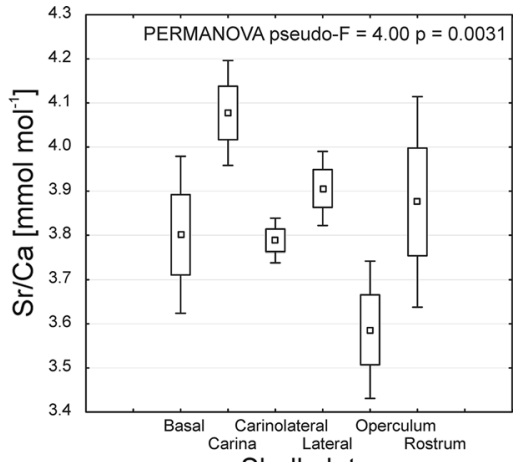

Shell plate
Fig. 4 Variation in element concentrations between shell plates (mean, standard error and 1.96*standard error) for each element separately. The diagrams are only for elements with statistically significant differences. $t$ values for statistically significant post hoc tests: lateral plates and operculum: $t=8.22, P<0.001$; lateral plates and basal plates: $t=3.08, P=0.005$; carina and

Table 3 The full output from the multivariate two-way PERMANOVA examining effect of two factors influencing shell chemistry, and interactions between them

\begin{tabular}{lllll}
\hline Factor & df & Pseudo- $F$ & $P$ value & Permut. \\
\hline Depth & 1 & 0.73 & 0.54 & 9957 \\
Fjord & 1 & 3.05 & $\mathbf{0 . 0 3}$ & 9942 \\
Depth \& Fjord & 1 & 1.09 & 0.36 & 9956 \\
\hline
\end{tabular}

Statistically significant $P$ value is bolded

analysed samples (B20-B26) were collected from the same station (1b), at a $50 \mathrm{~m}$ depth.

\section{Discussion}

We found different accumulation patterns for different trace elements in barnacle shell plates that may indicate biological control of element uptake and biomineralization processes in cirripedes. Based on our results, the operculum was shown to be the most distinctive shell plate, and it exhibited higher ratios of $\mathrm{Mg} / \mathrm{Ca}$ and $\mathrm{S} / \mathrm{Ca}$ and lower ratios of $\mathrm{Sr} / \mathrm{Ca}$ compared to other shell plates (Fig. 4). In marine calcifiers, the increased content of $\mathrm{Mg}$ is known to enhance the mechanical properties of biogenic minerals. Numerous studies on echinoids have indicated that higher $\mathrm{Mg}$ content can increase hardness, stiffness and elastic modulus (e.g. Ma et al., 2009; Moureaux et al., 2010; Long et al., 2014), and a similar relationship in operculum: $t=9.62, P=0.001$; carina and basal plates: $t=2.62, \quad P=0.018 ; \quad$ rostrum and operculum: $t=8.02$, $P=0.001$; basal plates and operculum: $t=2.77, P=0.016$; carinolateral and operculum: $t=7.45, P=0.003$; rostrum and basal plates: $t=2.34, P=0.041$

cirripedes calcite is likely. However, to our knowledge, there is a lack of studies on the influence of $\mathrm{Mg}$ concentrations on shell mechanical properties in barnacles. On the other hand, higher sulphur concentrations may indicate a greater content of organic material in the calcareous lattice (Lorens \& Bender, 1980; Vander Putten et al., 2000). In calcitic shells of brachiopods, Cusack et al. (2008) found sulphur in a form of sulphate and sulphur-containing amino acids (proteins), whereas Gorzelak et al. (2013) recorded that in crinoids calcite sulphur was associated with sulphated polysaccharides. In addition, Gorzelak et al. (2013) observed that high $\mathrm{Mg}$ concentrations in the skeleton were correlated with the distribution of sulphates, and this pattern agrees with our results (Fig. 4). The presence of organic biomolecules plays a significant role in the process of biomineralization, such as transient stabilization of amorphous calcium carbonate or regulation of $\mathrm{Mg}$ content (e.g. Politi et al., 2004; Hermans et al., 2011). Organic material can also influence mechanical properties of biogenic carbonate, contributing to ductility (Meyers et al., 2008). It is likely that the combination of both high $\mathrm{Mg}$ and high organic molecules content enhances hardness, crushing resistance and other mechanical properties of opercular plates. The operculum is a movable lid; with an open operculum, an organism can put out its feathery legs (cirri) and then capture food in the form of detritus or microorganisms. However, a closed operculum serves as a leak-proof barrier to ensure effective isolation from adverse environmental 
Fig. 5 Concentrations (mean, standard error and $1.96 \times$ standard error) of all the studied elements in $B$. balanus shells collected from the different fjords and depths. Only statistically significant PERMANOVA is given
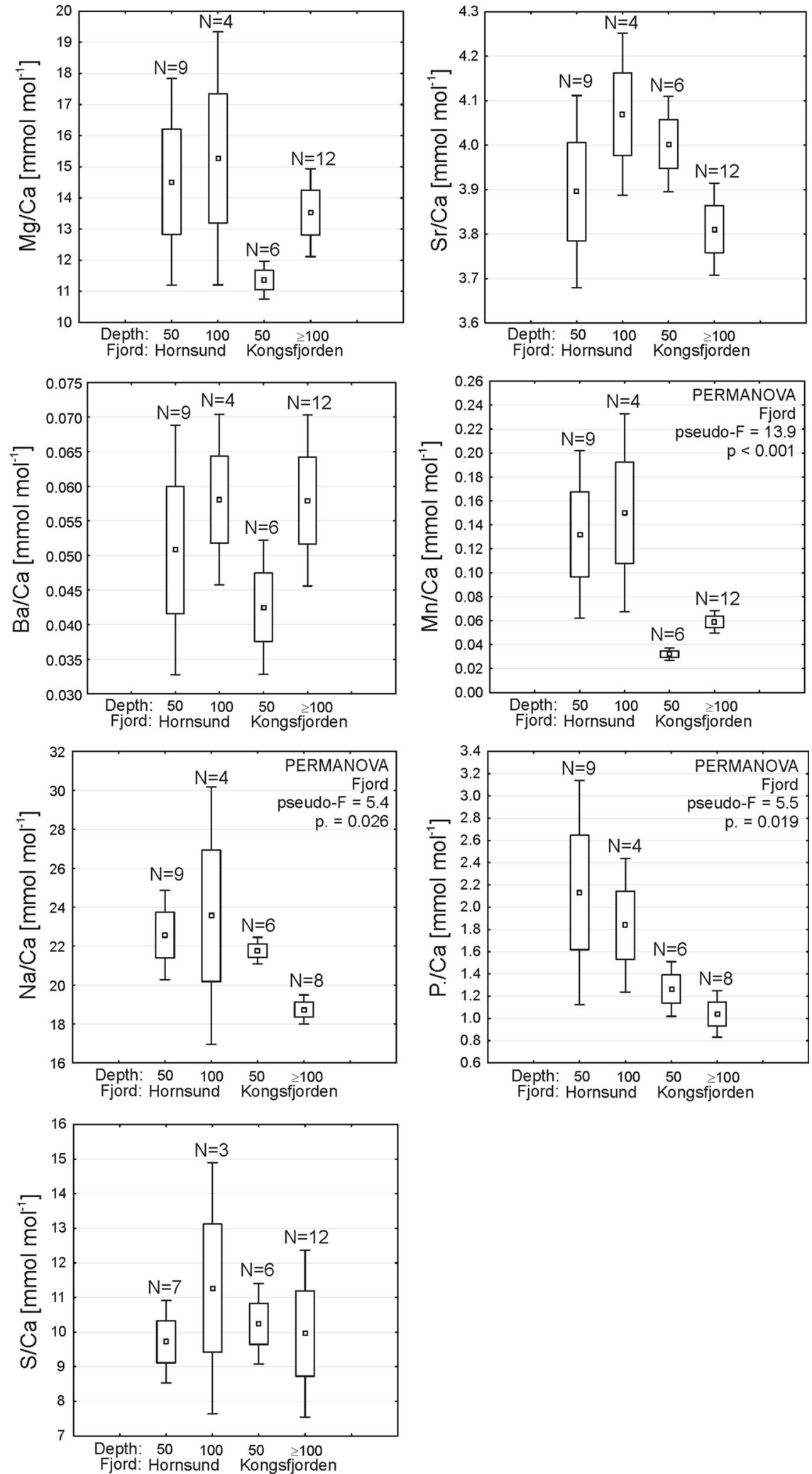


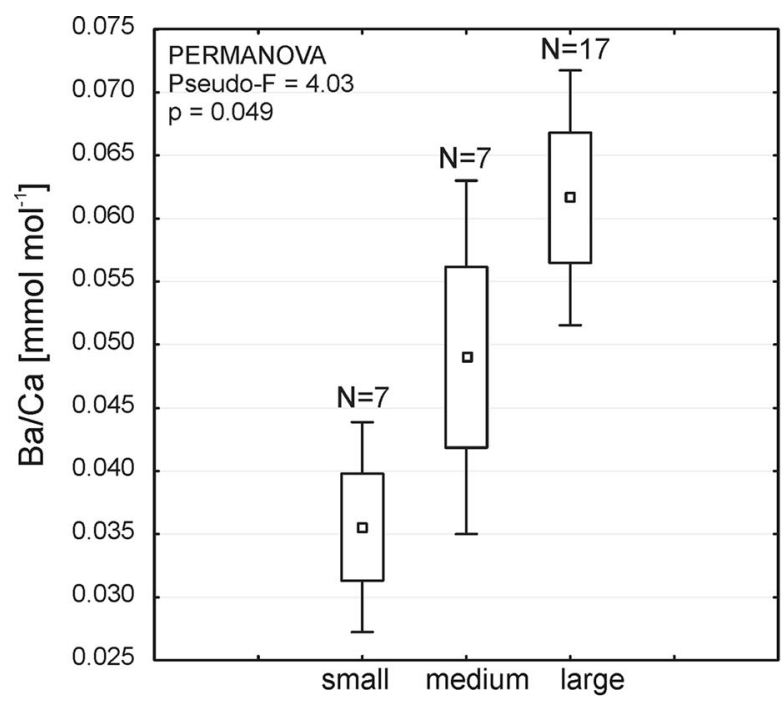

Fig. 6 Differences (mean, standard error and $1.96 \times$ standard error) in the $\mathrm{Ba} / \mathrm{Ca}$ and $\mathrm{Na} / \mathrm{Ca}$ ratios related to shell size. Significant differences between 'large' and 'small' size classes

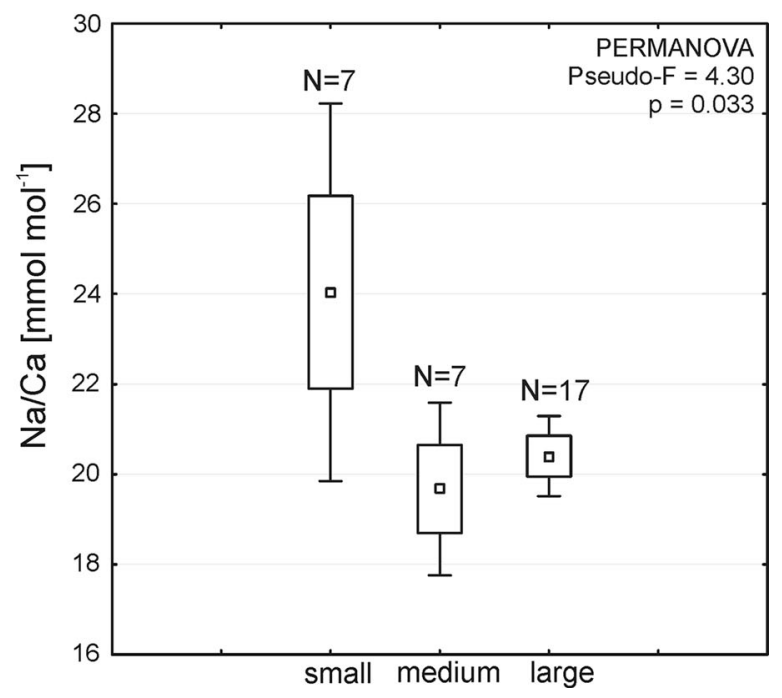

confirmed by post hoc tests: $\mathrm{Ba} / \mathrm{Ca} t=3.05, P=0.005$ and Na/ Ca $t=2.41, P=0.020$

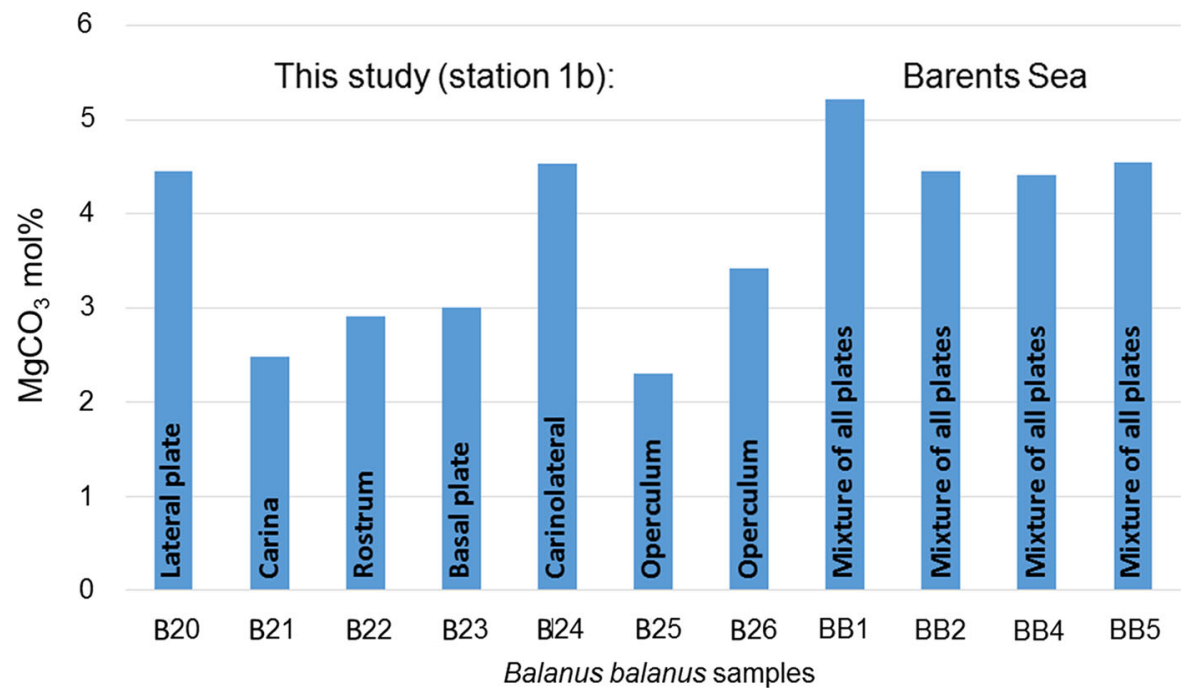

Fig. 7 The XRD measurements of $\mathrm{MgCO}_{3}$ concentrations in the shells from this study (samples B20-B26, station $1 \mathrm{~b}, 50 \mathrm{~m}$ depth) in comparison with Balanus balanus specimens (BB1-

conditions, and this ability is likely to have a high adaptive value. The specific chemical composition of an operculum may be related to the required mechanical properties of this shell part, and this finding leads to the possible explanation that this organism regulates the accumulation pattern within its shell, because such regulation increases its adaptive properties.
BB5) collected from the Barents Sea (Iglikowska unpublished results; station coordinates: N76 48.66 E22 55.47 , depth: $102 \mathrm{~m}$, date of collection: August 2015)

Cirripedes permanently adhere to substrates by secreting proteinaceous glue (Dickinson et al., 2016). In the adhesive interface of Amphibalanus (= Balanus) amphitrite basal plate, authors recorded phosphorus associated with the organic matrix (phosphoproteins), and these compounds were found to contribute to the adhesive properties of the glue and probably played a role in biomineralization 
(Dickinson et al., 2016). In this study, the basal plates of $B$. balanus were characterized by relatively low $\mathrm{P} / \mathrm{Ca}$ ratios (Appendix 2-Supplementary material), but based on our results, we cannot ascertain whether the phosphorus was associated with organic material or was a component of inorganic mineral.

The results of this study demonstrate that the concentration of certain elements may correspond with barnacle shell size. In the studied $B$. balanus specimens, we observed a positive correlation between shell size and the $\mathrm{Ba} / \mathrm{Ca}$ ratio (Spearman's $R=0.62, P<0.05$ ), i.e. with progressing growth, the $\mathrm{Ba}$ concentration increases in the lateral shell plates (Fig. 6). The possible explanation for this result is that no mechanism exists to remove this element from calcified shell, and thus, older specimens, accumulating barium for a longer time, were characterized by higher $\mathrm{Ba} / \mathrm{Ca}$ ratios. Generally, in the studied barnacles, Ba had the lowest concentrations in the shell compared to other elements, whereas in other taxa (e.g. bivalves: Demina et al., 2012) relatively high Ba concentrations were reported. Although this result can be attributed to shell mineralogy (calcitic barnacles versus aragonitic or bimineralic bivalves), since more open orthorhombic aragonite lattice can more readily incorporate large $\mathrm{Ba}$ ions comparing to tight calcite structure.

Another element that significantly varied in the lateral plates with size was sodium (Fig. 6). Marine invertebrates contain generally high concentrations of $\mathrm{Na}$ most likely because of the high availability of sodium in ambient seawater (e.g. Gordon et al., 1970; Amiel et al., 1973; Demina et al., 2012; Iglikowska et al., under review). In medium and large barnacle specimens, we recorded significantly lower Na content compared to small individuals (Fig. 6). This observation may suggest a presence of regulatory mechanisms in barnacles to remove sodium from the shell calcite, and older individuals are likely to be more efficient in $\mathrm{Na}$ elimination. However, this observation needs further examination especially in controlled laboratory conditions.

It is interesting that different barnacle species exhibit highly variable concentrations of strontium. In our study, $\mathrm{Sr}$ was present in minor concentrations in $B$. balanus shells, whereas in Balanus eburneus, Pilkey and Harris (1966) found that $\mathrm{Sr}$ contents are significantly higher, comparable to $\mathrm{Mg}$ concentrations. A study by Hockett et al. (1997) indicated that there were extremely low $\mathrm{Sr} / \mathrm{Ca}$ levels in the shells of Amphibalanus (= Balanus) amphitrite (mean $\mathrm{Sr} / \mathrm{Ca}$ from 0.005 to $0.071 \mathrm{mmol} \mathrm{mol}^{-1}$ ), significantly lower than our study on B. balanus ( $\mathrm{Sr} / \mathrm{Ca} 3.12-4.35 \mathrm{mmol} \mathrm{mol}^{-1}$ ). It appears that the uptake and accumulation of strontium in barnacle shells are, to a large extent, speciesspecific and thus most likely controlled biologically. However, we cannot completely exclude the role of environmental factors such as temperature, salinity and seawater $\mathrm{Sr}$ concentrations in shaping strontium accumulation in the cirriped shells (e.g. Hockett et al., 1997). In Semibalanus balanoides, Watson et al. (1995) observed that, depending on site location, the shell $\mathrm{Sr}$ content showed opposite trends, i.e. Sr content increased or decreased with increasing shell weight, which may indicate a significant role of environmental variables in regulating $\mathrm{Sr}$ levels.

In the present study, we compared the shell chemistry of $B$. balanus specimens collected from two different fjords and from two different depths. Hornsund and Kongsfjorden fjords vary in terms of their physical and chemical seawater properties. Despite the fact that Kongsfjorden is located further north compared to Hornsund, we observed higher water temperatures at all studied depths. Additionally, Kongsfjorden was characterized by a slightly lower seawater $\mathrm{pH}$, lower concentration of carbonate ions, higher concentration of $\mathrm{CO}_{2}$, lower saturation with calcite and higher salinity (Iglikowska et al., 2017). We also found some differences in shell chemistry depending on site location. Specimens collected in Hornsund were characterized by higher concentrations of Mn, Na and P (Fig. 5), whereas the trends for other elements were less clear. Gordon et al. (1970) noted that the content of manganese in barnacle shells is directly correlated with environmental Mn concentrations of ambient seawater. Additionally, the authors suggested that the Mn found in shells is derived from the manganese adsorbed on ingested seston. Demina et al. (2016) claimed that Mn tends to adsorb on the shell surface, particularly in species characterized by high shell porosity. It is likely that $\mathrm{Mn}$ adsorption is shaped mainly by environmental influences (e.g. presence of clay particles, or hydroxides); however, on the basis of our results, we cannot reliably determine whether detected $\mathrm{Mn}$ is incorporated in the crystal lattice or adsorbed on the shell surface.

Several studies (e.g. Rucker \& Valentine, 1961; Pilkey \& Goodell, 1964; Gordon et al., 1970) reported 
that the dominant factor influencing shell concentrations of $\mathrm{Na}$ is salinity, and with higher salinity, higher sodium concentrations are expected, although this interdependence is not confirmed by our results. Generally, in the less saline Hornsund fjord, we found higher skeletal $\mathrm{Na}$ concentrations than in the Kongsfjorden fjord that is characterized by higher salinity (Fig. 5). These records may be ascribed to periodic local changes in habitat, since our data on seawater chemistry are only snap-shot observations that do not reflect long-term salinity conditions.

In the present study, several shell plates were selected to examine their shell mineralogy, and all of the plates were $100 \%$ calcitic, with low $\mathrm{MgCO}_{3}$ concentrations, which is consistent with the results of other authors for cold-water barnacles (e.g. Pilkey \& Harris, 1966; Bourget, 1977). We compared the $\mathrm{MgCO}_{3}$ concentrations from this study with previous results from the Barents Sea (Fig. 7, Iglikowska unpublished results), and values appeared to be slightly higher in the Barents Sea. This result may suggest that $\mathrm{Mg}$ content cannot be solely determined biologically, but environmental factors can, to some extent, also affect magnesium concentrations in barnacle shells. It is likely that the influence of environmental conditions on the $\mathrm{Mg}$ content in barnacle shells is more apparent when we consider specimens collected from locations characterized by significantly different physical and chemical seawater conditions. In this study, the seawater properties were less variable showing comparable values at the studied stations, and therefore, in this case, biological control appears to have a more decisive role in controlling the $\mathrm{Mg}$ concentrations in barnacle shells.

\section{Conclusion}

The results presented in this study reveal that a barnacle shell is a chemically complex structure, and trace elements vary depending on shell plates, species and environmental factors. Cirripedes seem to be able to modulate the distribution of some elements within the whole shell, which is likely determined by natural selection. The uptake and accumulation of some elements (i.e. $\mathrm{Mg}, \mathrm{S}, \mathrm{Sr}, \mathrm{Na}$ ) are likely under biological control of the organism. On the other hand, the effect of environmental variables on trace element deposition in calcareous shells is documented by numerous reports (e.g. Gordon et al., 1970; Watson et al., 1995). This study also revealed some evidence of environmental control, yet this relationship appears to be very complex, and it is difficult to identify the specific variable influencing $B$. balanus elemental concentration. Therefore, our results do not allow us to reject the presented hypotheses that (1) the chemical composition of the $B$. balanus shell is mostly controlled biologically, with minor influences from environmental factors and that (2) the chemical composition of $B$. balanus shells did not vary between size classes.

Acknowledgements The research leading to these results received funding from the Polish-Norwegian Research Programme operated by the National Centre for Research and Development under the Norwegian Financial Mechanism 2009-2014 in the frame of Project Contract No Pol-Nor/ $196260 / 81 / 2013$. The publication has been also financed by the budget of the Polish National Science Center Grant (UMO2014/15/B/NZ8/00237).

Open Access This article is distributed under the terms of the Creative Commons Attribution 4.0 International License (http:// creativecommons.org/licenses/by/4.0/), which permits unrestricted use, distribution, and reproduction in any medium, provided you give appropriate credit to the original author(s) and the source, provide a link to the Creative Commons license, and indicate if changes were made.

\section{References}

Amiel, A. J., G. M. Friedman \& D. S. Miller, 1973. Distribution and nature of incorporation of trace elements in modern aragonitic corals. Sedimentology 20: 47-64.

Anderson, M. J., 2001. Permutation tests for univariate or multivariate analysis of variance and regression. Canadian Journal of Fisheries and Aquatic Sciences 58: 626-639.

Anderson, M., R. N. Gorley \& R. K. Clarke, 2008. Permanova + for primer: guide to software and statistical methods. PRIMER-E Ltd, Plymouth.

Andersson, A. J., F. T. Mackenzie \& N. R. Bates, 2008. Life on the margin: implications of ocean acidification on $\mathrm{Mg}$ calcite, high latitude and cold-water marine calcifiers. Marine Ecology Progress Series 373: 265-274.

Barnes, H. \& M. Barnes, 1954. The general biology of Balanus balanus (L.) da Costa. Oikos 5: 63-76.

Bourget, E., 1977. Shell structure in sessile barnacles. Le Naturaliste Canadien 104: 281-323.

Bourget, E., 1987. Barnacle shells: composition, structure and growth. In A. J. Southward (ed.), Barnacle Biology. AA Balkema, Rotterdam: 267-285. 
Buckeridge, J. S., 2012. Opportunism and the resilience of barnacles (Cirripedia: Thoracica) to environmental change. Integrative Zoology 7: 137-146.

Bulling, M. T., N. Hicks, L. Murray, D. M. Paterson, D. Raffaelli, P. C. White \& M. Solan, 2010. Marine biodiversityecosystem functions under uncertain environmental futures. Philosophical Transactions of the Royal Society of London B 365: 2107-2116.

Clarke, K. R. \& R. N. Gorley, 2006. Primer. Primer-E, Plymouth.

Cottier, F., V. Tverberg, M. Inall, H. Svendsen, F. Nilsen \& C. Griffiths, 2005. Water mass modification in an Arctic fjord through cross-shelf exchange: the seasonal hydrography of Kongsfjorden, Svalbard. Journal of Geophysical Research 110(110): C12.

Cusack, M., Y. Dauphin, J. P. Cuif, M. Salomé, A. Freer \& H. Yin, 2008. Micro-XANES mapping of sulphur and its association with magnesium and phosphorus in the shell of the brachiopod, Terebratulina retusa. Chemical Geology 253: $172-179$.

Darwin, C., 1854. A monograph of the sub-class Cirripedia. Ray Society, London.

Demina, L. L., S. V. Galkin \& O. M. Dara, 2012. Trace metal bioaccumulation in the shells of mussels and clams at deepsea hydrothermal vent fields. Geochemistry International 50: $133-147$.

Demina, L. L., N. S. Oskina \& S. V. Galkin, 2016. Trace metal accumulation in carbonate biominerals of the Atlantic Ocean. Oceanology 56: 131-136.

Dickinson, G. H., X. Yang, F. Wu, B. Orihuela, D. Rittschof \& E. Beniash, 2016. Localization of phosphoproteins within the barnacle adhesive interface. The Biological Bulletin 230: $233-242$.

Drewnik, A., J. M. Węsławski, M. Włodarska-Kowalczuk, M. Łącka, A. Promińska, A. Zaborska \& M. Głuchowska, 2016. From the worm's point of view. I: environmental settings of benthic ecosystems in Arctic fjord (Hornsund, Spitsbergen). Polar Biology 39: 1411-1424.

Feely, R. A., C. L. Sabine, J. M. Hernandez-Ayon, D. Ianson \& B. Hales, 2008. Evidence for upwelling of corrosive "acidified" water onto the continental shelf. Science 320: 1490-1492.

Findlay, H. S., M. A. Kendall, J. I. Spicer \& S. Widdicombe, 2009. Future high $\mathrm{CO}_{2}$ in the intertidal may compromise adult barnacle Semibalanus balanoides survival and embryonic development rate. Marine Ecology Progress Series 389: 193-202.

Gordon, C. M., R. A. Carr \& R. E. Larson, 1970. The influence of environmental factors on the sodium and manganese content of barnacle shells. Limnology and Oceanography 15: 461-466.

Gorzelak, P., J. Stolarski, M. Mazur \& A. Meibom, 2013. Microand nanostructure and geochemistry of extant crinoidal echinoderm skeletons. Geobiology 11: 29-43.

Grzelak, K. \& L. Kotwicki, 2012. Meiofaunal distribution in Hornsund fjord, Spitsbergen. Polar Biology 35: 269-280.

Gutmann, W. F., 1960. Funktionelle Morphologie von Balanus balanoides. Abhandlungen der Senckenbergischen Naturforschenden Gesellschaft 500: 1-43.

Hermans, J., L. André, J. Navez, P. Pernet \& P. Dubois, 2011. Relative influences of solution composition and presence of intracrystalline proteins on magnesium incorporation in calcium carbonate minerals: insight into vital effects. Journal of Geophysical Research 116: G01001.

Hockett, D., P. Ingram \& A. LeFurgey, 1997. Strontium and manganese uptake in the barnacle shell: electron probe microanalysis imaging to attain fine temporal resolution of biomineralization activity. Marine Environmental Research 43: 131-143.

Hop, H., T. Pearson, E. N. Hegseth, K. M. Kovacs, J. M. Weslawski, C. Wiencke, S. Kwasniewski, K. Eiane, R. Leakey, S. Cochrane, M. Zajaczkowski, O. J. Lønne, F. Mehlum, C. Lydersen, B. Gulliksen, S. Falk-Petersen, M. Poltermann, S.-Å. Wängberg, M. Kendall, K. Bischof, A. Y. Voronkov, N. A. Kovaltchouk, G. W. Gabrielsen, M. WlodarskaKowalczuk, J. Wiktor, G. di Prisco, A. Estoppey, C. Papucci \& S. Gerland, 2002. The marine ecosystem of Kongsfjorden, Svalbard. Polar Research 21: 167-208.

Hönisch, B., A. Ridgwell, D. N. Schmidt, E. Thomas, S. J. Gibbs, A. Sluijs, R. Zeebe, L. Kump, R. C. Martindale, S. E. Greene, W. Kiessling, J. Ries, J. C. Zachos, D. L. Royer, S. Barker, T. M. Marchitto, R. Moyer, C. Pelejero, P. Ziveri, G. L. Foster \& B. Williams, 2012. The geological record of ocean acidification. Science 335: 1058-1063.

Iglikowska, A., J. Bełdowski, M. Chełchowski, M. Chierici, M. Kędra, J. Przytarska, A. Sowa \& P. Kukliński, 2017. Chemical composition of two mineralogically contrasting Arctic bivalves' shells and their relationships to environmental variables. Marine Pollution Bulletin 114: 903-916.

Ito, H. \& S. Kudoch, 1997. Characteristics of water in Kongsfjorden, Svalbard. Proceedings of the National Institute of Polar Research Symposium on Polar Meteorology and Glaciology 11: 211-232.

Jørgensen, L. L. \& B. Gulliksen, 2001. Rocky bottom fauna in arctic Kongsfjord (Svalbard) studied by means of suction sampling and photography. Polar Biology 24: 113-121.

Klepal, W. \& H. Barnes, 1975. A histological and scanning electron microscope study of the formation of the wall plates in Chthamalus depressus (Poli). Journal of Experimental Marine Biology and Ecology 20: 183-198.

Lippert, H., K. Iken, E. Rachor \& C. Wiencke, 2001. Macrofauna associated with macroalgae in the Kongsfjord (Spitsbergen). Polar Biology 24: 512-522.

Long, X., Y. Ma \& L. Qi, 2014. Biogenic and synthetic high magnesium calcite: a review. Journal of Structural Biology 185: $1-14$.

Lorens, R. B. \& M. L. Bender, 1980. The impact of solution chemistry on Mytilus edulis calcite and aragonite. Geochimica et Cosmochimica Acta 44: 1265-1278.

Ma, Y., B. Aichmayer, O. Paris, P. Fratzl, A. Meibom, R. A. Metzler, Y. Politi, L. Addadi, P. U. P. A. Gilbert \& S. Weiner, 2009. The grinding tip of the sea urchin tooth exhibits exquisite control over calcite crystal orientation and $\mathrm{Mg}$ distribution. Proceedings of the National Academy of Sciences 106: 6048-6053.

Mackenzie, F., W. Bischoff, F. Bishop, M. Loijens, J. Schoonmaker \& R. Wollast, 1983. Magnesium calcite: low-temperature occurrence, solubility and solid-solution behaviour. In R. J. Reeder (ed.), Carbonates: Mineralogy and Chemistry Reviews in Mineralogy. Mineralogy Society of America, Washington, DC: 97-143. 
McDonald, M. R., J. B. McClintock, C. D. Amsler, D. Rittschof, R. A. Angus, B. Orihuela \& K. Lutostanski, 2009. Effects of ocean acidification over the life history of the barnacle Amphibalanus amphitrite. Marine Ecology Progress Series 385: 179-187.

Meyers, M. A., P. Y. Chen, A. Y. M. Lin \& Y. Seki, 2008. Biological materials: structure and mechanical properties. Progress in Materials Science 53: 1-206.

Moureaux, C., A. Perez-Huerta, P. Compère, W. Zhu, T. Leloup, M. Cusack \& P. Dubois, 2010. Structure, composition and mechanical relations to function in sea urchin spine. Journal of Structural Biology 170: 41-49.

Newman, W. A. \& D. P. Abbott, 1980. Cirripedia: the barnacles. In R. H. Morris, D. P. Abbott \& E. C. Haderlie (eds), Intertidal Invertebrates of California. Stanford University Press, Stanford: 504-535.

Pilkey, O. H. \& R. C. Harris, 1966. The effect of intertidal environment on the composition of calcareous skeletal material. Limnology and Oceanography 11: 381-385.

Pilkey, O. H. \& H. G. Goodell, 1964. Comparison of the composition of fossil and recent mollusk shells. Geological Society of America Bulletin 75: 217-228.

Politi, Y., T. Arad, E. Klein, S. Weiner \& L. Addadi, 2004. Sea urchin spine calcite forms via a transient amorphous calcium carbonate phase. Science 306: 1161-1164.

Rainbow, P. S., 1984. An introduction to the biology of British littoral barnacles. Field Studies 6: 1-51.

Rainbow, P. S., 2006. Biomonitoring of trace metals in estuarine and marine environments. Australasian Journal of Ecotoxicology 12: 107-122.
Roberts, D. A., S. N. Birchenough, C. Lewis, M. B. Sanders, T. Bolam \& D. Sheahan, 2013. Ocean acidification increases the toxicity of contaminated sediments. Global Change Biology 19: 340-351.

Rucker, J. B. \& J. W. Valentine, 1961. Salinity response of trace element concentration in Crassostrea virginica. Nature 190: 1099-1100.

Smith, I. F., 2015. Introduction to barnacle morphology and identification. http://www.flickr.com/photos/ 56388191@N08/collections/72157633613346690/.

Svendsen, H., A. Beszczynska-Moller, J. O. Hagen, B. Lefauconnier, V. Tverberg, S. Gerland, J. B. Orbaek, K. Bischof, C. Papucci, M. Zajączkowski, R. Azzolini, O. Bruland, C. Wiencke, J. G. Winther \& W. Dallmann, 2002. The physical environment of Kongsfjorden-Krossfjorden, an Arctic fjord system in Svalbard. Polar Research 21: 133-166.

Vander Putten, E., F. Dehairs, E. Keppens \& W. Baeyens, 2000. High resolution distribution of trace elements in the calcite shell layer of modern Mytilus edulis: environmental and biological controls. Geochimica et Cosmochimica Acta 64: 997-1011.

Walczowski, W., 2013. Frontal structures in the West Spitsbergen Current margins. Ocean Science 9: 957.

Watson, D., P. Foster \& G. Walker, 1995. Barnacle shells as biomonitoring material. Marine Pollution Bulletin 31: 111-115. 